Article

\title{
Export-Oriented Horticultural Production in Laikipia, Kenya: Assessing the Implications for Rural Livelihoods
}

\author{
Anne Ulrich \\ Department of Geography, South Asia Institute, Heidelberg University, Im Neuenheimer Feld 330, \\ Heidelberg 69120, Germany; E-Mail: ulrich@sai.uni-heidelberg.de; Tel.: +49-6221-54-4398; \\ Fax: +49-6221-54-5926
}

Received: 25 October 2013; in revised form: 18 December 2013 / Accepted: 20 December 2013 / Published: 8 January 2014

\begin{abstract}
Smallholders in the global South are confronted with new opportunities and risks emanating from globalized markets of agricultural goods. In Kenya, large-scale export-oriented horticulture farms, cultivating fruits, flowers and vegetables, were by and large established in the 1980s. In Laikipia County, the farms have grown to be the most important employers tying the region into global markets. The growth of the industry has direct as well as indirect impacts on local livelihoods. Based on qualitative data gathered from 55 interviews held with experts, local households and employees, the assessment shows a range of economic, social and environmental opportunities as well as constraints. Three major shortcomings are identified, the first being increasing river water abstractions and related water scarcity, second the call for living wages and social security, and third constraints smallholders face as out-growers. Addressing these issues can contribute to a more sustainable development in the region.
\end{abstract}

Keywords: livelihoods; smallholder; horticulture; agriculture; rural development; Laikipia; Kenya

\section{Introduction}

Smallholders in peripheral regions of the global South are confronted with new opportunities and constraints due to globalized markets of agricultural goods. In East Africa high potential mountain areas have long been integrated in global value chains for the production of coffee and tea. A rather new development is the production of horticulture crops (fruits, flowers, vegetables) for export, which has pushed into areas under more arid conditions that are therefore more prone to resource contestation, 
as is the case in Laikipia, Kenya. The expansion of horticultural agro-businesses places pressure on limited natural resources, especially water, which can aggravate the situation for ecosystems and downstream users. At the same time, it offers new economic opportunities. In Kenya, horticultural production has been the second most important foreign exchange earner in the agricultural sector, after tea, over the past decade [1]. The economic implications on-site are debated controversially. On the one hand, the growing market for horticulture products has been proposed as a pro-poor strategy due to the sector's high labour requirements and the opportunities it offers to commercialize small-scale farms [2,3]. On the other hand, critics argue that the increased globalization in the agri-food sector does not benefit the poor. The main arguments raised are that the increase and stringency of product and process standards act as new non-tariff barriers and that farmers are unfairly exploited by multinational food companies [4,5]. Other studies have highlighted an increasing dependency on, and regulation of, agricultural practices through global value chains in rural Kenya [6,7]. It is argued that within this system smallholders are increasingly being marginalized [8-10]. To understand the industry's impact at the local level, this study places smallholders in the centre of the analysis. Applying a livelihood approach [11,12], the study draws attention to the impacts, both direct and indirect, that globalized markets of agricultural goods (can) have on rural populations. Within the context of a growing export-oriented horticulture production in Laikipia, the paper aims to give an overview of economic, environmental and social implications for smallholders in the region. This assessment then identifies three major shortcomings that need to be addressed, not only for further research, but also for policy formulations that can contribute to sustainable development in the region.

\section{Study Area and Data Base}

Laikipia County in Kenya is a semi-arid region situated on a highland plateau emerging off the north-west slope of Mount Kenya with an altitude of between 1600 and 2300 m [13]. It spans a total area of $9700 \mathrm{~km}^{2}$, at its western edge it is bordered by the Great Rift and its lakes. The Samburu Plains and lowlands are found to the north of the district. The Aberdare Range (3999 m) and Mount Kenya (5199 $\mathrm{m})$ form the southern to south-eastern border.

Up to 75 percent of the rural population in the region are considered small-scale farmers, with $\sim 1-3$ ha land per household, on which they carry out a combination of crop farming and livestock keeping. They face harsh ecological conditions with limited and erratic rainfall regimes (600-700 mm p.a.) coupled with declining water resources, increasing land degradation and high erodibility of soils. Water availability has been identified as the most limiting factor for agriculture [13,14]. Export-oriented horticultural farms were by and large established in the 1980s and have since grown to be the most important employers. Twenty-four large horticultural farms were established between 1991 and 2003 with a labour force of 4700-7400 persons and a total area of 1085 ha [13]. The sector intricately ties the region into global markets as never before. Neither the coffee and tea nor the tourism sectors have had as noticeable an impact in the county [13].

The study is based on qualitative data gathered from 55 interviews held with local stakeholders and from four months of field observations in Laikipia, Kenya. The data collected is supplemented with an extensive literature review. The semi-structured interviews included standardized questions followed by an open discussion about individual experiences and opinions. Focus was directed particularly at 
the experiences of local smallholder households (30 households interviewed), of the employees at one of the large-scale horticultural farms (15) and of contracted out-growers (5). The farmers were selected from a former livelihood survey in 1997 [14] which was based on a random selection of 10 percent of the local population. Purposive sampling of 15 households that have at least one household member working on one of the large horticultural farms, as well as 15 households without members associated with the industry was carried out. From there, a snowball sampling technique was used to find workers and out-growers from within the neighbourhood. Furthermore, expert interviews were held with farm managers (2) and government officials (1) as well as local scientists (2). These were more arbitrarily selected; subject to availability and willingness to respond. While the results are not representative, the study does explore the various dimensions in which the industry impacts on smallholder livelihoods. The topics covered in the interviews ranged from working conditions, income earned and assets accumulated, to infrastructure and knowledge transfer as well as environmental and social impacts (Table 1).

Table 1. Overview of various livelihood aspects covered in the interviews, their classification into five capitals, and the respective interview partners.

\begin{tabular}{|c|c|c|}
\hline Capital & Topic covered in interviews & $\begin{array}{l}\text { Interview } \\
\text { partner * }\end{array}$ \\
\hline Human & $\begin{array}{l}\text { Working conditions: health and safety, working hours, discrimination, etc.; } \\
\text { Technology and knowledge transfer for the household; } \\
\text { Perception of technology and knowledge transfer for the region }\end{array}$ & $\begin{array}{l}a, b, c \\
a, b, c \\
a, b, c, d, e\end{array}$ \\
\hline Financial & $\begin{array}{l}\text { Salary; } \\
\text { Income from contract production; } \\
\text { Reliance of income flow/salary; } \\
\text { Perception of the importance of income/job within household and compared } \\
\text { to other livelihood strategies; } \\
\text { Perception of the importance of income/job opportunities in the region; } \\
\text { Opportunity cost (What would they do otherwise); } \\
\text { Remittance to others (Who else benefits); } \\
\text { Other benefits (e.g., pension) }\end{array}$ & $\begin{array}{l}\text { a,b } \\
\mathrm{c} \\
\mathrm{a}, \mathrm{b}, \mathrm{c} \\
\mathrm{a}, \mathrm{b}, \mathrm{c} \\
\mathrm{a}, \mathrm{b}, \mathrm{c}, \mathrm{d}, \mathrm{e} \\
\mathrm{a}, \mathrm{b}, \mathrm{c} \\
\mathrm{a}, \mathrm{b}, \mathrm{c} \\
\mathrm{a}, \mathrm{b}, \mathrm{c}\end{array}$ \\
\hline Physical & $\begin{array}{l}\text { Assets accumulated due to job/contract farming; } \\
\text { Assets accumulated compared to gains from other livelihood strategies; } \\
\text { Perception of accumulation opportunities for the region; } \\
\text { Investment in infrastructure by company }\end{array}$ & $\begin{array}{l}\text { a,b,c } \\
\text { a,b,c } \\
\text { a,b,c,d,e } \\
\text { a,b,c,d,e }\end{array}$ \\
\hline Natural & $\begin{array}{l}\text { Impacts on environment that directly effects household; } \\
\text { Impacts on environment that effects the region/neighbourhood; } \\
\text { Measures taken by the company against negative impacts on environment }\end{array}$ & $\begin{array}{l}\text { a,b,c } \\
\text { a,b,c,d,e,f } \\
\text { a,b,c,d,f }\end{array}$ \\
\hline Social & $\begin{array}{l}\text { Impacts on household and region; } \\
\text { Opportunities and constraints for households to participate within the industry; } \\
\text { Information about standards and respective constraints for out-growers; } \\
\text { Changes in duties and workload for household members; } \\
\text { Overtime work and consequences for intra-household work; } \\
\text { Measures taken by the company in the field of social implications }\end{array}$ & $\begin{array}{l}\text { a,b,c,d,e } \\
\text { a,b,c,d,e } \\
\text { c } \\
\text { a,b,c } \\
\text { a,b,c,d } \\
\text { a,b,c }\end{array}$ \\
\hline
\end{tabular}




\section{Implications for Smallholder Livelihoods: An Overview}

To show the different aspects of how smallholders are directly and indirectly affected by the development of the expanding horticultural production in the region, a broad classification into economic, environmental and social dimensions is drawn. There is no weight given as to which impacts are more relevant than others, particularly as the respondents are not necessarily representative. It is rather a perspective given, that highlights the relations with other aspects of local well-being. The overview in the following sections is exclusively based on empirical data from the interviews. The results are then analysed and compared to the literature in the discussion that follows.

\subsection{Economic Opportunities and Constraints}

It was widely recognized by the respondents that the industry has positive economic impacts on the region as a whole and on individual households through new employment opportunities or new market possibilities. First, it offers an alternative income opportunity; particularly for the unskilled workforce and for women. Many employees at one of the horticultural farms stated that if they did not have the job, they would most likely work on their family's farm. While this off-farm opportunity increases the work load for those household members remaining on the farm, it also provides for an additional liquid income. The study showed that employment at a commercial farm - as long as it is a permanent position - is important for households' livelihood opportunities in terms of gaining assets, investment in housing and education. However, as the majority within the case study are employed on a casual basis, in most cases, it is not the primary source of income and subsistence farming still plays a dominant role in farmers' livelihoods. Other negative factors that were associated with employment at a commercial farm include low wages ( $1.40-2.90$ US\$ per day) and poor working conditions; such as overtime work, health risks and insecure employment tenure related to seasonality and lack of due notice. Second, the industry influences smallholder livelihoods through out-grower programs, where farmers are recruited to grow produce on their own farms. Within the case study these farmers were in general relatively well off. The advantages named by contracted out-growers were, improved access to markets, price guarantees, the avoidance of middle men and brokers, and the availability of support from out-grower extension services and technical advisors. Third, the region's infrastructure is strengthened through road construction and the introduction of new technologies such as irrigation systems, pipes and dams constructed by the horticulture industry.

\subsection{Environmental Opportunities and Constraints}

For the local population a major impact on the environment comes about through the rising demand on the already scarce water resources. Due to the irrigation needs of the large farms, river water abstraction has grown tremendously, which is compounded further by increased water abstraction due to continuous population growth in the region. This situation is particularly problematic as the region lies at the juncture of the highlands and lowlands at the foot-slopes of Mount Kenya. Tensions between upstream and downstream users (large commercial farms, smallholders, pastoralists, nature conservationists, etc.) have been reported by many of those interviewed. Water Resource User Associations (WRUA) were established from 1998 onwards to counter the conflicts between different 
stakeholders, whilst aiming to secure the environmental functions of river basins. Farmers, however, repeatedly mentioned that the success of the WRUAs is limited, and water projects run by them do not work. Whilst many poor households are excluded as they cannot afford the obligatory monthly payment. A government official within the Water Resource Management Authority (WRMA) said that power relations were an issue. For example, the permission needed for river water abstraction was said to be readily given to commercial farms and less so to smallholder groups. It must be said, however, that the industry invests in new technologies (drip irrigation, water storage) to improve water conservation, and this was noted positively by the community. Another issue of great concern to the respondents was the use of chemicals. They felt that the increased use of agro-chemicals impacts negatively on water and soil quality and is perceived to bring new crop diseases.

\subsection{Social Opportunities and Constraints}

The expanding industry influences different social dimensions of local livelihoods. First, the industry offers learning opportunities not only for the workforce in the upgrading of agricultural skills (like irrigation and farming methods) and training on safe chemical use and health issues, but also through technology transfer to the wider community through the construction of greenhouses, boreholes or irrigation systems. On the other hand it was reported that the number of school drop-outs has risen due to the opportunity of earning cash at the farms. Second, serious health problems related to working conditions in one of the farms were mentioned. These included cold and chest problems due to working in cold rooms and late at night, as well as back pains and dehydration. One main issue leading to these symptoms was considered to be the lack of or insufficient provision of protective clothing against cold or chemicals. This is particularly worrying as workers who are sick or injured were reported to be laid off without remuneration. Respondents further complained that the river, often their only water source, is polluted with agro-chemicals and poses a health risk to downstream users. Third, other impacts were more closely linked to family and gender issues, such as labour shortage at the home farm due to the absence of the workforce and corresponding work overload, particularly for women. Within households, impacts noted by the respondents were a fragmentation of the family unit or reconfigurations of work tasks. Fourth, the industry has impacts on the community as a whole. The generation of employment was said to help curb insecurity due to reduced idleness. In-migration attracted by the opportunities of commercial farm jobs leads to new business opportunities on the one hand but increases competition for labour vacancies, as well as it places more demand on natural resources, on the other hand. Several commercial farms engage in community development through corporate volunteering; examples are the building of health centres, classrooms, dams or school sponsorships.

Summarising the implications for smallholders with regard to the expanding horticultural market in their region, Figure 1 shows the dimensions in which livelihoods are affected. Based on the Sustainable Livelihood Approach [11] an asset pentagon is used to illustrate the impacts along five core types of capital; namely human, natural, financial, physical and social capital. It becomes clear that the capitals reflect the economic, environmental and social opportunities and constraints explored above. Contextualising the results within the framework shows how external developments impact local lives in multiple ways and thus proves suitable for assessing the contribution as well as threats to 
sustainable development in the region. While other studies analyse the direct impacts for employees with a focus on income [15], on working conditions and gender [16-18] on health [19], or economic aspects at the national level [3], this paper stresses the various implications on the wider socio-ecological conditions in which the farms are embedded. The assessment not only highlights where further research is necessary, but also identifies pathways that could support smallholders in benefiting from the expanding market whilst avoiding negative livelihood outcomes.

Figure 1. Implications of the expanding horticultural production for smallholder livelihoods: An overview.

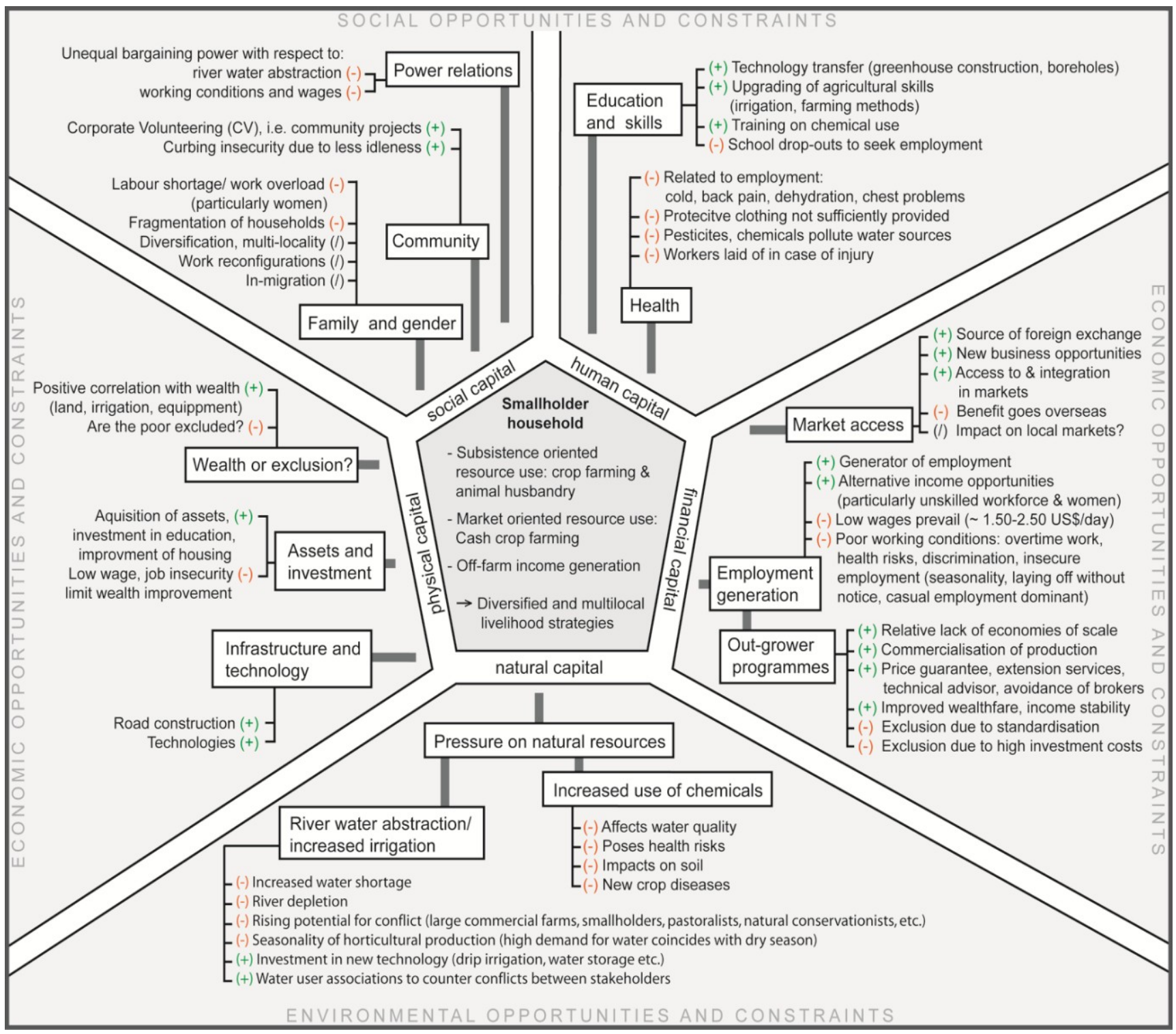

\section{Discussing Challenges for Sustainable Development}

The results from the interviews show diverse impacts on economic, environmental and social aspects of local livelihoods. While the expanding horticulture industry offers important employment opportunities and technology transfer, there are several negative issues that need further attention. 


\subsection{Water Scarcity}

Most respondents were concerned about declining water quality and its availability. Out of the 45 farmers and employees interviewed, 31 pointed towards the problem of limited water availability due to upstream users' abstraction and blocking or diverting of the river flow. This perception is confirmed by studies that provide evidence of a significant decline in downstream discharge of major river systems (during the dry season, from $9 \mathrm{~m}^{3} / \mathrm{s}$ in the $1960 \mathrm{~s}$ to less than $1 \mathrm{~m}^{3} / \mathrm{s}$ in the 1990s) even though the rainfall regime has not shown significant change. The studies attribute the decline mainly to regional land use changes associated with increasing population (from 60,000 residents in 1960 to 230,000 in 1989, and 400,000 in 2009 [20,21] and growing demand for river water to support irrigated agricultural production [13,22-25]. In the present study 11 farmers directly stated that the horticultural farms were the main abstractor, while others argue that smallholders are the main abstractors due to the use of inefficient irrigation methods as compared to the large-scale farms. Kiteme et al. [13] emphasize that the industry created a new dimension of water demand in the area. The water shortage might be further exacerbated during the period of high demand in the horticultural sector (during the autumn and winter in the northern hemisphere), which corresponds largely with the dry season in the study area. Schuler [26,27] highlights a "[...] strong opponent pattern between the scarcity of the natural resources and the profitability of the use of the same resources for horticultural purposes". In light of farmers having identified limited water resources as the most important constraint for their livelihood [14,28], questions must be raised on how to best contribute to sustainable water use; including modalities for fair access to water, options for effective water storage and addressing underlying issues such as unequal power relations between different user groups. There appears to be more scope for research in identifying modalities aimed at addressing user demands and environmental needs in a more sustainable fashion. One approach in this direction are common intakes. Introduced to WRUAS by the Water Resource Management Authority it aims to share water more equitable among the members within the sub-catchment. It ensures distribution of river water from the same point to all members and further secures a constant minimal reserve river flow through a self-regulating weir. This mechanism can strengthen sustainable water management and will help mitigate against water conflicts as it contributes towards equitable water access. Further scope exists to improve on water projects in the area, as out of six water supply systems mentioned by the respondents only one was functioning. This indicates that there are management problems that need to be addressed in order to counter water shortages more effectively. Questions arise as to how water projects and initiatives can be maintained in the long run.

Decline in water quality was another issue of concern to the respondents. Out of 45 farmers and employees interviewed, 20 argued that water resources (and soil) have become polluted due to the chemicals used by the horticultural farms. It is well known that pesticide use can have adverse effects on human health, environment and eco-systems [29], and global concerns are reflected in the increasing stringency of standards on pesticide residue levels [30]. However, mechanisms for controlling pesticide use and sale in developing countries is limited [29]. In light of this and taking local people's concerns seriously, more research is needed on the social and ecological impacts of pesticide use in the region, as well as on how pest and disease management can be changed from chemical based to healthier and ecologically friendly methods [30]. 


\subsection{Living Wage}

The interviews with employees at one of the large horticultural farms revealed a strong claim for higher wages. Each of the fifteen workers interviewed stated that they wished for a salary increment when asked about the measures the companies should take to improve their social and environmental performance. For the majority this was the only measure that they wish for. Thus, it is important to have a closer look at the issue of living wages and poverty outcomes. A range of literature covers poverty outcomes for small-scale farmers from opportunities provided by horticultural trade but the results are not conclusive $[2,4,5,15,27,31]$. It is argued that horticultural production can contribute to the range of options that rural people employ to improve their living standards, as it is a relatively profitable form of production, creates employment opportunities through high labour requirement and increases commercialization of the rural sector [3]. The off-farm employment increases household liquidity and can be reinvested in seeds, fertilizers and other farm products for subsistence or commercial farming. The labour demand is mainly in the unskilled segment of the workforce with jobs such as chopping, washing, labelling and bar coding [32]. The number of temporary and female workers is high. In the Kenyan flower industry these figures are estimated at 65 percent and 75 percent respectively [16]. They are particularly vulnerable due to lower pay and lack of employment security $[16,17,33]$. While the off-farm activities have the potential to increase well-being of the local population, a longitudinal livelihood survey conducted in the region found that existing low levels of pay and highly insecure employment conditions reduce their ability to sustainably build up capital [28]. Leipold and Morgante ([34]: p. 12) confirm these findings in their Kenyan study and state that "wages are significantly below a living wage" that enable an acceptable minimum living standard. Workers and their family thus have no or only limited disposal income for savings and to contribute to domestic consumption [34]. This confirms findings by Oxfam [18] and Miller and William [35] that show that minimum wages set in many developing countries do not cover basic needs of workers and their families, and argue that the issue of a living wage need to be addressed urgently. Note must be taken, however, that wages are not higher in other unskilled off-farm jobs in the area. Certainly, in a country with a high unemployment rate (12,7 percent in 2005/06 [36,37]) and high poverty rates (46 percent in 2006 [38]), there is a need for further deliberations on what constitutes a living wage and how it impacts on poverty and labour economics [39]. In this discussion the importance of freedom of association and right to collective bargaining (ILO Conventions 87 and 98) is stressed, in order to provide the means needed for improving wages and conditions of working. In an environment where these rights are recognized, companies and policy makers must then engage in a dialogue with local communities and in negotiations with representatives of the workforce [35]. Only then can workers benefit from globalization processes, not only for the improvement of individual living conditions, but also to stimulate growth and domestic consumption, and not least, in light of the Corporate Responsibility movement where the majority of international companies have signed respective codes of conducts (e.g., ETI base code).

\subsection{Out-Grower Programs and Participation}

During the field work it became apparent that those households that were supplying produce to one of the large-scale horticultural farms via out-grower programs were amongst the relatively well-off in 
the region. This highlights both the potential for smallholders to benefit from export markets as well as the limitation that only those with the requisite capacity (knowledge, material, finance) are able to participate. The significance of contract farming in developing countries is widely debated [40]. Contract farming and the formation of producer organizations has been recommended by the World Bank as one way to promote a commercial orientation for smallholders and to bring agriculture to the market [41]. Associated with the market for horticultural produce, however, is the rising number of increasingly more stringent quality standards that aim to meet end-consumer demands and food safety concerns. These require costly investments in physical facilities and human skills $[4,10]$. Smallholders' continued participation in the expanding market is therefore determined by their capacity to adapt to the increasing requirements of traceability and quality management and compliance with emerging standards [8]. In a case study of green bean producers in Kenya, Okello [10] found that international food safety standards are likely to marginalize resource-poor farmers. He showed, however, that through joining together in cooperative groups and joint investment, the main barrier, which is the lack of financial capital, can be overcome. Further research is needed to ensure for the participation of smallholders in the global horticultural and other growing agricultural markets, as well as the role of collective action in this respect [42].

\section{Conclusions and Future Perspectives}

The study identified a number of implications for smallholders emanating from globalized horticultural production in Laikipia County. Direct and indirect impacts were felt in social, economic as well as environmental dimensions. The study showed the importance to assess these implications from a local perspective; it highlighted research needs and identified entry points towards a more sustainable development.

Contestation over natural resources and over-extraction were recognized by the respondents as being among the most pressing challenges for them. Local concerns of decreasing water resources due to river water abstractions, where the large-scale horticultural farms play a considerable role, must be taken seriously. Mechanisms such as common intakes and self-regulating weirs serve as good examples to contribute to a minimal reserve flow and to counter potential conflicts over the resource. Scope for research exists on the potential for collective action and capacity building to improve water resource management. Further, there is a need to examine the degree of pesticide pollution and its impacts on both the ecosystem and the health of the local population.

Despite the industry's importance for employment opportunities in the region, low wages hamper positive economic impacts for the employees. For the respondents, salary increments were the most important measure that must be undertaken by the companies. However, more research is needed to heighten the debate on living wages, how it can be measured and how barriers for introduction can be overcome. Focus should also be directed to how freedom of association and the right to collective bargaining can be fostered.

Farmers that were supplying to one of the large-scale horticultural farms via an out-grower program were amongst the relatively well-off in the region. This led to a discussion about the potential, as well as limitations, this offers for market access and rural development. In order to participate in expanding export markets, farmers need support in enhancing their ability to adapt to increasing requirements of 
traceability, quality management and compliance with emerging standards. More research is needed to understand how smallholders can overcome these barriers.

For all three issues, the common underlying constraint for smallholders lies in their unequal bargaining position with the large commercial farms. Power constellations are an important aspect to consider. In this regard, collective action emerges as a future approach that can support and strengthen smallholders' interests. As an example, one way could be through the formation of farmer groups with shared interests, be it for water storage or irrigation improvements, be it in labour unions to discuss working conditions and wage raises, or be it to overcome costly investments for contracted out-growers that need to comply with increasing standardization.

\section{Acknowledgments}

The research for this publication was conducted in the context of the project "Semi-arid areas in transition: Livelihood security, socio-ecological variability and the role of development interventions in East Africa" funded by the Volkswagen Foundation. The author is grateful to the communities and experts that took part in the study, as well as to Marcus Nüsser, Urs Wiesmann, Boniface Kiteme, Chinwe Ifejika Speranza, Paul Roden and the CETRAD team for their support and valuable discussions.

\section{Conflicts of Interest}

The author declares no conflict of interest.

\section{References}

1. Swinnen, J.F.M.; Maertens, M. Globalization, privatization, and vertical coordination in food value chains in developing and transition countries. Agric. Econ. 2007, 37, 89-102.

2. Minten, B.; Randrianarison, L.; Swinnen, J.F.M. Global Retail Chains and Poor Farmers: Evidence from Madagascar; Discussion Paper 164; Katholieke Universiteit: Leuven, Belgium, 2006.

3. Weinberger, K.; Lumpkin, T.A. Diversification into horticulture and poverty reduction: A research agenda. World Dev. 2007, 35, 1464-1480.

4. Asfaw, S.; Mithöfer, D.; Waibel, H. What impact are EU supermarket standards having on developing countries' export of high-value horticultural products? Evidence from Kenya. J. Int. Food Agribus. Market. 2010, 22, 252-276.

5. Maertens, M.; Colen, L.; Swinnen, J.F.M. Globalisation and poverty in Senegal: A worst case scenario? Eur. Rev. Agric. Econ. 2011, 38, 31-54.

6. Ouma, S. Global standards, local realities: Private agrifood governance and the restructuring of the Kenyan horticulture industry. Econ. Geogr. 2010, 86, 197-222.

7. Dannenberg, P.; Nduru, G.M. Practices in international value chains: The case of the Kenyan fruit and vegetable chain beyond the exclusion debate. Tijdschrift voor Economische en Sociale Geografie 2013, 104, 41-56.

8. Jensen, M. Developing New Exports from Developing Countries: New Opportunities and New Constraints. Ph.D. Thesis, The Royal Veterinary and Agricultural University, Copenhagen, Denmark, 2004. 
9. Augier, P.; Gasiorek, M.; Lai Tong, C. The impact of rules of origin on trade flows. Econ. Policy 2005, 20, 567-624.

10. Okello, J.J. The role of collective action in overcoming the challenges of European food safety standards: The case of Kenya's french bean and nile perch industries. Int. Res. J. 2011, 1, 30-37.

11. Department for International Development (DFID). Sustainable Livelihood Guidance Sheet; DFID: London, UK, 1999.

12. Scoones, I. Livelihoods perspectives and rural development. J. Peasant Stud. 2009, 36, 171-196.

13. Kiteme, B.; Liniger, H.P.; Notter, B.; Wiesmann, U.; Kohler, T. Dimensions of Global Change in African Mountains: The Example of Mount Kenya. In International Human Dimensions Programme on Global Environmental Change: Mountainous Regions: Laboratories for Adaptation; Rechkemmer, A., Ed.; International Dimensions Programme on Global Environmental Change: Bonn, Germany, 2008; Volume 2.

14. Wiesmann, U. Sustainable Regional Development in Rural Africa: Conceptual Framework and Case Studies from Kenya; Geographica Bernensia: Bern, Switzerland, 1998; Volume A14, p. 286.

15. McCulloch, N.; Ota, M. Export Horticulture and Poverty in Kenya; Ids Working Paper 174; Institute of Development Studies: Brighton, UK, 2002.

16. Barrientos, S.; Kritzinger, A.; Opondo, M.; Smith, S. Gender, Work and Vulnerability in African Horticulture; IDS Bulletin; Institute of Development Studies: Brighton, UK, 2005; Volume 36, pp. 74-79.

17. Tallontire, A.; Dolan, C.; Smith, S.; Barrientos, S. Reaching the marginalised? Gender value chains and ethical trade in African horticulture. Dev. Pract. 2005, 15, 559-571.

18. Raworth, K. Trading Away Our Right: Women Working in Global Supply Chains; Oxfam International: Oxford, UK, 2004.

19. Cross, P.; Edwards, R.T.; Opondo, M.; Nyeko, P.; Edwards-Jones, G. Does farm worker health vary between localised and globalised food supply systems? Environ. Int. 2009, 35, 1004-1014.

20. Kenya National Bureau of Statistics (KNBS). Kenya National Population Census. Laikipia; KNBS: Nairobi, Kenya, 1989.

21. Kenya National Bureau of Statistics (KNBS). Kenya National Population Census. Laikipia; KNBS: Nairobi, Kenya, 2009.

22. Gichuki, F.N.; Liniger, H.P.; MacMillan, L.; Schwilch, G.; Gokonyo, G. Exploring resource availability, use and improved management. East. South. Afr. J. 1998, 8, 15-28.

23. Ngigi, S.N.; Savenije, H.H.G.; Gichuki, F.N. Land use changes and hydrological impacts related to up-scaling of rainwater harvesting and management in upper Ewaso Ng'iro river basin, Kenya. Land Use Policy 2007, 24, 129-140.

24. Aeschbacher, J.; Liniger, H.; Weingartner, R. River water shortage in a highland-lowland system. Mount. Res. Dev. 2005, 25, 155-162.

25. Liniger, H.; Gikonyo, J.; Kiteme, B.; Wiesmann, U. Assessing and managing scarce tropical mountain water resources. Mount. Res. Dev. 2005, 25, 163-173.

26. Schuler, R. Commercial Horticulture North-West of Mt. Kenya: A Sector Analysis with Emphasis on Implications on River Water Resources of the Upper Ewaso Ng'iro Basin. Master Thesis, University of Bern, Bern, Switzerland, 2004. 
27. Minot, N.; Ngigi, M. Are Horticultural Exports a Replicable Success Story?: Evidence from Kenya and Côte D'ivoire; Eptd Discussion Paper 120; International Food Policy Research Institiute (IFPRI): Washington, DC, USA, 2004.

28. Ulrich, A.; Ifejika Speranza, C.; Roden, P.; Kiteme, B.; Wiesmann, U.; Nüsser, M. Small-scale farming in semi-arid areas: Livelihood dynamics between 1997 and 2010 in Laikipia, Kenya. J. Rural Stud. 2012, 28, 241-251.

29. Atreya, K.; Sitaula, B.K.; Bajracharya, R.M. Pesticide use in agriculture: The philosophy, complexities and opportunities. Sci. Res. Essays 2012, 7, 2168-2173.

30. Macharia, I.N.; Mithöfer, D.; Waibel, H. Potential environmental impacts of pesticide use in the vegetable sub-sector in Kenya. Afr. J. Horticul. Sci. 2009, 2, 138-151.

31. Henson, S. The role of public and private standards in regulating international food markets. J. Int. Agric. Trade Dev. 2008, 4, 63-81.

32. Dolan, C.; Humphrey, J. Governance and trade in fresh vegetables: The impact of UK supermarkets on the African horticulture industry. J. Dev. Stud. 2000, 37, 147-176.

33. Dolan, C.S. Benevolent intent? The development encounter in Kenya's horticulture industry. J. Asian Afr. Stud. 2005, 40, 411-437.

34. Leipold, B.; Morgante, F. The impact of the flower industry on Kenya's sustainable development. Int. Public Policy Rev. 2012, 7, 1-31.

35. Miller, D.; Williams, P. What price a living wage? Implementation issues in the quest for decent wages in the global apparel sector. Glob. Soc. Policy 2009, 9, 99-125.

36. United Nations Development Programme (UNDP). Kenya's Youth Employment Challenge; Discussion Paper; UNDP: New York, NY, USA, 2013.

37. Vuluku, G.; Wambugu, A.; Moyi, E. Unemployment and underemployment in Kenya: A gender gap analaysis. Economics 2013, 2, 7-16.

38. United Nations (UN). A New Global Partnership: Eradicate Poverty and Transform Economies through Sustainable Development; UN: New York, NY, USA, 2013.

39. Anker, R. Estimating a Living Wage: A Methodological Review. In Conditions of Work and Employment Programme; Series No. 29; International Labour Office (ILO): Geneva, Switzerland, 2011; Volume 29, pp. 1-132.

40. Oya, C. Contract farming in sub-saharan Africa: A survey of approaches, debates and issues. J. Agrar. Change 2012, 12, 1-33.

41. World Bank. World Development Report 2008: Agriculture for Development; World Bank Publications: Washington, DC, USA, 2007.

42. Wiesmann, U.; Kiteme, B. Threats and Opportunities for Smallholders in Rural Development. In Evidence for Policy Series, Global Edition; NCCR North-South: Bern, Switzerland, 2013; Volume 12.

(C) 2014 by the author; licensee MDPI, Basel, Switzerland. This article is an open access article distributed under the terms and conditions of the Creative Commons Attribution license (http://creativecommons.org/licenses/by/3.0/). 